\title{
Evaluación del comportamiento expansivo de las rocas y su interés en conservación
}

\author{
Swelling behaviour of stones and its interest in conservation. \\ An appraisal
}

\author{
J.DELGADORODRIGUES \\ Lab. Nacional de Ingeniería Civil, Lisboa
}

Fecha de recepción: 5-VII-2001

PORTUGAL

\section{RESUMEN}

La expansibilidad puede ser definida como el incremento de volumen que un cuerpo sólido experimenta cuando es humedecido. Muchos tipos litológicos (rocas carbonatadas, areniscas, rocas igneas) tienen componentes expansivos en su composición; la anhidrita y los minerales arcillosos son los dos componentes expansivos más conocidos. La expansibilidad puede ser medida con facilidad y la determinación de la presión de hinchamiento se puede efectuar en muchos laboratorios de geotecnia. Este trabajo trata del problema de la degradación de los materiales rocosos debida a la expansión de las arcillas y-discute las formas de tenerla en cuenta cuando interesa evaluar la durabilidad de esos materiales. Se analiza el papel de la expansibilidad en la conservación de la piedra y se hace una revisión de algunos casos en los que la degradación por expansión tiene un papel relevante, explicito o implicito.

\section{SUMMARY}

Swelling can be defined as the volume increase experienced by any solid body when wetted. Many lithotypes (carbonate rocks, sandstones, igneous rocks) have expansive components in their composition; anhydrite and clay minerals are the two best-known expansive components in stone materials. Swelling strain can be easily quantified and swelling pressure determination is accessible in many geotechnical laboratories. This paper deals with the decay of stone due to swelling of clays and discusses the ways to take the swelling behaviour into account when the assessment of stone durability is concerned. It analyses the role of swelling in stone conservation and reviews some cases where this decay mechanism has a relevant role, explicit or implicitly.

\section{INTRODUCCIÓN}

La expansibilidad por hinchamiento se puede definir como el incremento de volumen experimentado por cualquier cuerpo sólido cuando se humedece. Este fenómeno es muy común y se asocia típicamente con dos procesos diferentes: la hidratación de compuestos cristalinos y la adsorción y/o absorción de agua en los espacios existentes, dentro o entre las partículas de las arcillas y de algunos otros minerales que poseen estructuras cristalinas peculiares. La transformación de anhidrita en yeso es el ejemplo mejor conocido del primer tipo, mientras que el comportamiento expansivo de las esmectitas puede señalarse como un ejemplo del segundo tipo de proceso.

\section{INTRODUCTION}

Swelling can be defined as the volume increase experienced by any solid body when wetted. This phenomenon has a very widespread occurrence and is typically associated to two distinct processes: the hydration of crystalline substances and to the intraand interparticle adsorption and absorption of water by clay and a few other minerals having peculiar crystalline structures. The transformation of anhydrite into gypsum is the best known example of the first type, while the expansion behaviour of smectites can be pointed out as an example of the second type. 
Muchos litotipos tienen componentes expansibles. La anhidrita está presente en algunas rocas carbonatadas, mientras que los minerales arcillosos pueden existir en una gran variedad de rocas, o como componentes primarios en las rocas sedimentarias o como minerales secundarios en rocas ígneas y metamórficas.

Las arcillas son componentes frecuentes en la fracción clástica de rocas sedimentarias; derivan de los procesos de meteorización que afectaron a las rocas formadoras de esta fracción. Las calizas y las areniscas pueden contener cantidades más o menos elevadas de arcillas y las consecuencias de este hecho pueden ser fácilmente observadas en los grandes afloramientos de estos litotipos.

En el caso de las rocas ígneas, las arcillas tienen siempre un origen secundario ya que se formaron por transformación química de los minerales primarios de la roca. Este fenómeno puede ocurrir en dos ambientes: a gran profundidad, en el interior de la Tierra; en la proximidad de zonas magmáticas o cerca de la superficie, donde prevalecen las condiciones atmosféricas. Las transformaciones del primer tipo se denominan alteración deutérica, mientras que el término meteorización se refiere al segundo tipo.

La presencia de arcillas en el interior de una roca es siempre potencialmente negativa. Estos minerales pueden reducir la resistencia de la roca y afectar a otras propiedades físicas, pero su presencia es especialmente relevante en lo que concierne a su durabilidad. Muchos autores han tratado el tema de la expansibilidad de las rocas destacando, desde hace mucho tiempo, el papel de las arcillas en la durabilidad de estos materiales (1-11).

Además de los litotipos que contienen arcillas, también algunas otras rocas presentan un elevado potencial expansivo cuando se localizan en el exterior; tal como es el caso de la conocida serpentinita de Toscana (Marmo verde di Prato), extensamente empleada en muchos monumentos famosos de Florencia y de otros lugares $(12,13)$.

El tratamiento de los problemas de expansibilidad por hinchamiento tiene mayor tradición en trabajos geotécnicos que en la conservación del Patrimonio Histórico Construido. Esto puede tener su explicación por el hecho de que en la construcción de un edificio puede disponerse de medios económicos suficientes para seleccionar la mejor piedra, mientras que en los trabajos de geotécnia, normalmente hay que aceptar las alternativas menos costosas o tener que utilizar la roca disponible, cualquiera que sea el tipo y calidad. De hecho, en la preparación de áridos para hormigón se requiere cierta selección de los materiales; sin
Many lithotypes have expansive components in their composition. Anhydrite is present in some carbonate rocks, while clay minerals can occur in a large variety of rocks, either as a primary component in sedimentary rocks or as secondary minerals in igneous and metamorphic rocks.

Clays are frequent components of the clastic fraction of sedimentary rocks. They derive from previous rocks due to weathering processes acting upon them. More or less impure limestones and sandstones may contain higher or lower amounts of clays and the consequences of this fact can be easily identified in large outcrops of geological formations of these lithotypes.

For the case of igneous rocks, clays have always a secondary origin, and are formed by decomposition of the primary components, by means of chemical transformations in two main ambiences: deep inside the Earth, in the vicinity of the magmatic zones or close to the surface where atmospheric conditions prevail. The transformations of the first type are called deuteric alteration, while weathering refers to the second one.

The presence of clays inside a solid rock has always a negative potential. These minerals may reduce the rock strength and affect other physical properties, but they are mostly relevant when durability is concerned. Many authors have been dealing with rock swelling and have long ago pointed out the role clays play in the performance of rock (1-11).

Outside the clay-containing lithotypes, some other rock types have been shown to have a high swelling potential, such as the case of the well known serpentinite from Toscana ("Marmo verde di Prato"), extensively used in many famous monuments in Florence and elsewhere $(12,13)$.

The treatment of the swelling problem has a longer tradition in current geotechnical works than in the conservation of the Built Historic Heritage. This situation finds an explanation in the fact that the construction of buildings can sometimes afford to pay for the selection of the best varieties of stone while current geotechnical works have to accept less valuable alternatives or may be forced to use whatever type and quality of stone is available. In fact, for the preparation of aggregate for concrete, some selection 
embargo, para la construcción de rellenos o diques puede ser necesario utilizar materiales de muy baja calidad.

En muchas circunstancias, en trabajos geotécnicos, es importante ser capaz de predecir la durabilidad de los materiales rocosos, en particular cuando van a estar en contacto directo con medios agresivos. Muchos autores han tratado esta cuestión y se han utilizado varios procedimientos para este propósito.

Aunque en el Patrimonio Histórico Construido puede que no sea tan frecuente la incidencia de degradaciones graves por hinchamiento, este mecanismo de deterioro está lejos de ser irrelevante. Es sorprendente la escasez de trabajos que se ocupan de este mecanismo y la falta de tradición en la caracterización de materiales con vistas a la predicción de su comportamiento en relación con este fenómeno.

Las calizas y areniscas puras son usadas frecuentemente en el Patrimonio Histórico Construido pero cuando se examina cuidadosamente la bibliografia, se puede comprobar que las variedades rocosas con arcillas tampoco son raras, si bien, aunque se identifiquen las arcillas, no siempre se tiene en cuenta la importancia y las consecuencias de su presencia. No es previsible encontrar en circunstancias normales calizas y areniscas con alto contenido de arcilla, puesto que es de esperar que presenten un comportamiento deficiente y ningún experto constructor las habría usado. Sin embargo, en circunstancias particulares, incluso se han encontrado margas en obras interiores (14) y en monumentos expuestos al exterior; tal es el caso de algunas tumbas egipcias. $(11,15,16)$. Por otra parte, pequeñas cantidades de arcillas son frecuentes en las piedras de edificación, donde tienen una marcada influencia en su comportamiento, especialmente en lo que se refiere a su durabilidad.

En este trabajo se trata del deterioro de las rocas inducido por el hinchamiento de las arcillas y se presentan algunas técnicas para cuantificar los parámetros que definen la expansibilidad. También se discuten las formas de evaluar este comportamiento expansivo. Finalmente, se analiza el papel del hinchamiento en la conservación de la piedra y se revisan algunos casos en los que, implícita o explícitamente, este mecanismo de deterioro ha tenido un papel relevante.

\section{EL HINCHAMIENTO DE LAS ARCILLAS COMO MECANISMO DE DETERIORO}

Las arcillas son filosilicatos y, por tanto, tienen una marcada estructura laminar. Esta peculiar estructura is required, but the construction of embankments may be forced to use very poor quality materials.

In many circumstances, in geotechnical works, it is important to be able to predict the performance of stone materials, in particular when they are placed in direct contact with external aggressive environments. Many authors have been addressing this question and several methods have been used for this purpose.

Although the occurrence of severe degradation in the Built Historic Heritage may not be so frequent, this decay mechanism is far from being irrelevant. It is surprising to see the scarcity of works dealing with this mechanism and the lack of tradition on the characterisation of the materials envisaging the prediction of their behaviour facing this mechanism.

Pure limestones and sandstones are frequent but, when carefully looking through the bibliography, one can verify that clay-containing varieties are not so rare, but the presence of clays, although identified, is not always taken into full acount in terms of its importance and ultimate consequences. Limestones or sandstones with a very high clay content are not to be expected in normal circumstances, since they are likely to show very poor performance and an expert builder would not have used them. However, in very specific environments, even marls have been found in inside works (14) and in exposed monuments such as old egyptian tombs $(11,15$, 16). On the other hand, small amounts of clays are quite frequent in building stones, with marked influence in their overall performance, especially in terms of durability.

The paper deals with stone decay induced by the swelling of clays, and presents some techniques to quantify the swelling parameters. It also discusses the ways to assess this swelling behaviour. Finally, it analyses the role of swelling in the conservation of stone and reviews some cases where this decay mechanism has a relevant role, explicit-or implicitly.

\section{CLAY SWELLING AS A DECAY MECHANISM}

Clays are phyllosilicates with a pronounced laminar crystalline structure. Their peculiar structure can 
puede experimentar una expansión por hinchamiento cuando el agua, u otro líquido polar, interactúa con ella; es decir, en algunas arcillas llamadas expansivas, tales como las esmectitas, su red cristalina se puede expandir por un mecanismo de hinchamiento intrapartícular. En general, todas las arcillas presentan un tamaño de partícula muy fino y las interacciones electrostáticas juegan un papel significativo en su comportamiento; en estas circunstancias el agua puede romper el equilibrio entre partículas y dar lugar a otro tipo de expansión (mecanismo de hinchamiento interpartícular). El tipo e intensidad del hinchamiento que puede experimentar una roca por efecto de las arcillas, dependen de varios factores, como el tipo y cantidad de arcillas, de su distribución en el interior de la roca, de la magnitud de los espacios capaces de expandirse en el interior de las redes cristalinas y de la distancia entre partículas, así como de la composición y disponibilidad de las disoluciones que percolan a través de la roca.

El papel perjudicial de las arcillas deriva de su capacidad para inducir deformaciones en el interior de la roca. Cuando esta deformación está espacialmente restringida, los componentes arcillosos dan lugar a tensiones internas que pueden llegar a causar roturas. Los niveles de tensión alcanzados por hinchamiento son consecuencia de los factores internos y externos mencionados y pueden alcanzar valores extremadamente elevados. Varios autores han realizado medidas de estas tensiones de expansión y han demostrado la importancia de este mecanismo de deterioro. Por ejemplo, en muestras de rocas basálticas con esmectitas han sido medidas tensiones de expansión de $200 \mathrm{~kg} / \mathrm{cm}^{2}$. (aproximadamente $20 \mathrm{MPa}$ ) (17). Valores entre 5 y $13 \mathrm{MPa}$ fueron encontrados en margas de la formación Tebas (11). Estos valores extremadamente altos son suficientes para fracturar, incluso las rocas más resistentes.

Han sido citados casos de rocas, por ejemplo en excavaciones, que experimentaron una rápida degradación al ser liberadas de la presión de confinamiento y de enterramiento y ser expuestas al exterior, a pesar de su aspecto aparentemente fuerte. La presencia de arcillas expansibles por hinchamiento de sus redes cristalinas va frecuentemente asociada con este comportamiento excepcional. Cuando las arcillas presentes en la roca son de tipo no expansivo, las presiones de hinchamiento no alcanzan valores muy altos, pero la repetición de ciclos de hinchamiento y contracción, como consecuencia de condiciones alternantes de humedad, pueden conducir a la rotura por un mecanismo de fatiga progresiva de la masa rocosa.

Ensayos realizados en condiciones de expansión libre, han demostrado que el incremento de volumen es undergo swelling when water or other polar liquids interact with them. Some clays can expand their crystal lattice as an intraparticle swelling mechanism (expansive clays such as smectites), while others are non-expansive (kaolinite and illite). In general, clays occur as very fine-grained particles, where electrostatic interaction plays a significant role. In these circumstances, water can disturb the equilibrium and promote a second type of expansion - the interparticle swelling. The type and extent of swelling depend on several factors, namely on the type and amount of clays, on their form of occurrence inside the stone, on the interparticle and interlayer distances of clay particles, as well as on the composition and availability of percolating solutions.

The harmful role of clays derives from their capacity to induce deformation inside the rock skeleton. When this deformation is restrained from increasing, the clay components build up internal stresses, up to the point of causing rupture. The stress levels reached by swelling are a consequence of the internal and external factors mentioned above and they can reach extremely high values. Several authors have carried out measurements of these swelling stresses and the results clearly demonstrate the significance of this decay mechanism. For instance, swelling stresses as high as $200 \mathrm{~kg} / \mathrm{cm}^{2}$ (=20 MPa) have been measured (17) in some samples of smectite-containing basaltic rocks. Values between 5 and $13 \mathrm{MPa}$ were determined in marls from the Thebes formation (11). These extremely high values are enough to disrupt even the toughest rock.

Cases have been reported where rocks degrade very rapidly once exposed to outdoor conditions and released from their confining and overburdening pressures, as in excavations, in spite of their apparently strong appearance. The occurrence of intracrystalline expandable clays is frequently associated with these abnormal behaviours. When the clays present in the rock are of the nonexpansive type, swelling pressures do not reach such high values, but the repetition of swelling cycles as a consequence of alternating humidity conditions may also lead to rupture through a mechanism of progressive fatigue of the rock body.

Free swelling tests show that volume increase is faster in the first stages of water absorption, but the 
mayor en las primeras etapas de absorción de agua, pero el mecanismo de hinchamiento puede tener lugar en períodos muy largos, particularmente cuando se trata de materiales poco porosos. La extracción de las canteras elimina la presión de confinamiento y da lugar a bloques con superficies libremente accesibles; cuanto menores son los bloques mas fácil es el acceso del agua a su interior y, consiguientemente, más propensos serán al hinchamiento y degradación. Ésta es la razón por la cual la durabilidad ha sido siempre una preocupación en el estudio de los áridos rososos para la industria de la construcción.

\section{MEDIDAS Y ENSAYOS DEL COMPORTAMIENTO EXPANSIVO}

A partir de las consideraciones anteriores se puede deducir que la expansión por hinchamiento es consecuencia de un proceso en el cual los minerales arcillosos son la causa primordial. Teniendo en cuenta esto, el paso siguiente es encontrar el procedimiento adecuado para cuantificar estas consecuencias. La evaluación de la importancia del hinchamiento puede seguir dos caminos: uno, directo, en el cual se cuantifica la causa (por ejemplo, la cantidad de arcillas presentes en la roca) y otro, indirecto, por el cual sólo se evalúan los síntomas (por ejemplo, el tipo y magnitud del hinchamiento).

En general, las arcillas existentes en el interior de una roca poseen un tamaño de partícula muy pequeño, dificilmente visible con el microscopio óptico. Esto significa que su cuantificación por medio de esta técnica no es sencilla y que, cuando es posible, lleva implícita una gran incertidumbre. A pesar de estas dificultades, algunos autores han usado extensamente este instrumento e incluso han propuesto su uso para obtener valores que sirvan como criterio para predecir la durabilidad de las rocas a una escala regional $(1,18)$. Con el DRX, los minerales arcillosos pueden ser determinados con mayor exactitud (pero con un límite de detección del orden del 5\%) siempre que se usen patrones internos de calibración.

Los tests con azul de metileno se usaron para una cuantificación indirecta de la actividad de las arcillas. Este test fue diseñado originalmente para suelos (19, 20) pero puede ser de interés para los áridos rocosos (21); se mejoraron las técnicas de medida, encontrándose buenas correlaciones con el contenido de arcilla. (22).

El contenido de arcilla determinado por métodos directos es, obviamente, de gran interés y muy informativo, pero muchos métodos indirectos han sido desarrollados como alternativa o complemento. A pesar de su incapacidad para proporcionar valores mechanism of swelling can develop for very long periods, in particular when low porous materials are concerned. The quarrying processes eliminate the confining pressures and produce blocks with freely accessible surfaces. The smaller the blocks, the easier the access to their interior. With faster access of water and in the absence of confining pressures, blocks are more prone to swelling and to degradation, the reason why durability has been a permanent concern in the study of stone aggregates in the construction industry.

\section{MEASURING AND ASSESSING SWELLING BEHAVIOURS}

From the above considerations, it can be deducted that swelling is the visible consequence of a process in which clay minerals act as the primary cause. Having this in mind, the next required step is to find an appropriate way to quantify those consequences. The assessment of the importance of swelling can follow two main trends: a direct way in which the ultimate cause is quantified (i.e. the amount of clays present inside the rock) or the indirect one in which only the symptoms are assessed (i.e. the type and amount of swelling).

In general, clays are present inside the stones as very small size particles, hardly visible under the optical microscope. This means that their quantification is not simple and when possible it is accompanied with large uncertainties. In spite of this difficulty, some authors have used this instrument extensively and have even proposed to use the obtained values as criteria for predicting stone performance on a regional basis $(1,18)$. Under the $X R D$, clay minerals can be determined with a better approximation (but with threshold limits of detection in the order of 5\%), provided internal calibration standards are used.

The methylene blue test has been used for a direct quantification of clay activity. This test was first designed for soils $(19,20)$ but it can also be of interest for aggregate materials (21). This test has experienced several improvements in the measuring techniques and it has given good correlation with clay content (22).

The clay content determined by direct methods is obviously important and highly informative, but many indirect methods have been developed as alternatives or as complementary approaches to the problem. In spite of being unable to provide a 
cuantitativos del contenido de arcilla, los métodos indirectos compensan este inconveniente suministrando una información adicional sobre otras características que no son consideradas en la evaluación directa. Los métodos indirectos (al menos algunos de ellos) pueden ser no destructivos y, además, la evaluación del hinchamiento considera conjuntamente el papel de las arcillas, los rasgos texturales y la resistencia de la roca que restringen o condicionan la capacidad destructora final de las arcillas.

El test probablemente mejor conocido y definitivamente más sencillo consiste en la medida de la deformación por hinchamiento lineal en condiciones no confinadas. Ésta puede ser determinada de forma uniaxial $(23,24)$ o triaxial y en condiciones confinadas o no confinadas $(25,26)$. La experiencia ha demostrado que la deformación por hinchamiento está claramente relacionada con el contenido de arcilla y, consiguientemente, proporciona una buena estimación de la capacidad destructora de estos minerales.

La magnitud de la deformación por hinchamiento que una roca puede experimentar debido a la absorción de agua depende de la presión de confinamiento y tiene su valor máximo en situaciones no confinadas. Por otra parte, la máxima presión desarrollada por el hinchamiento de una roca tiene lugar en situaciones de confinamiento absoluto donde la deformación está impedida. La denominada "regla del hinchamiento" (swelling rule) fue obtenida experimentalmente por Huder y Amberg (27) y se muestra en la Figura 1, reproducida a partir de Kovari et al., 1988 (28).

También fue propuesto el uso de peróxido de hidrógeno para estimar el papel de las arcillas (3), al considerar que la descomposición del $\mathrm{H}_{2} \mathrm{O}_{2}$ produce moléculas de agua más reactivas que, consiguientemente, aumentan y aceleran la capacidad de hinchamiento de los minerales arcillosos presentes en el interior de la roca.
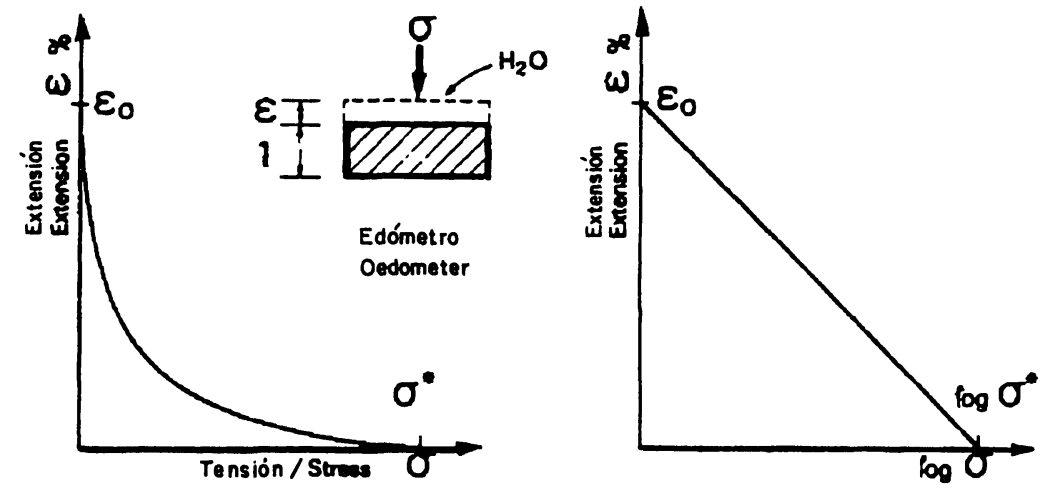

Figura 1.- La "regla del hinchamiento" para rocas arcillosas, obtenida a partir de tests con el edómetro (Huder y Amberg, 1970), reproducido de Kovári et al., 1988.

Figure 1.- The "swelling rule" for clay rocks, from oedometer tests (Huder and Amberg, 1970), reproduced from Kovári et al., 1988. 
Otros métodos se basan en el efecto del agua de reblandecer las rocas que contienen arcillas para obtener información acerca de la presencia y del papel de dichas arcillas. El test de durabilidad por desgaste en medio húmedo (slake durability test) evalúa la resistencia a la abrasión de fragmentos de piedra húmedos, o en condiciones naturales $(26,29,30)$ o después de haber sido tratados con etilenglicol (6). La relación entre la resistencia a compresión en húmedo (en condiciones de saturación) y en seco, se usa también para estimar el efecto de las arcillas en la disminución de la resistencia, aunque tal disminución puede deberse además de al hinchamiento de las arcillas, a otros mecanismos. Esta relación fue descrita en primer lugar por L. Tetmajer (31) y posteriormente adoptada por otros autores como un método para evaluar la durabilidad de las rocas $(8,32)$.

$L$ a reactividad, agua-roca fue considerada un buen indicador de la presencia de minerales arcillosos en el interior de una roca y, junto con la permeabilidad y la superficie específica, fue usada para predecir la durabilidad de los materiales rocosos (33), si bien para su determinación se requiere instrumental pesado.

Estos métodos han sido adoptados como criterios de evaluación o han sido sugeridos para predecir el comportamiento de los materiales que contienen arcillas, pero hasta el momento no ha habido ningún intento serio de hacer una puesta en común de las propuestas existentes o de elaborar alternativas reales a las existentes. En los párrafos siguientes se discuten algunos criterios disponibles, tratando de llevar este tema a un ámbito más general de discusión e intentando desarrollar mejores procedimientos para la resolución de este importante problema.

\section{LA EXPANSIÓN POR HINCHAMIENTO EN LA CONSERVACIÓN DE LA PIEDRA}

La determinación cuantitativa de la deformación por hinchamiento es directa y fácil. El equipamiento requerido es sencillo y barato, el procedimiento de laboratorio es muy rápido y los resultados reproducibles. No hay razones aparentes que expliquen la escasez de datos cuantitativos en la bibliografia, a menos que, desde nuestra perspectiva personal, hayamos sobreestimado la importancia de este parámetro.

Algunas de las publicaciones citadas producidas en el campo de la conservación de la piedra, mencionan, al menos, la expansibilidad de la piedra como un factor relevante en su deterioro. Sin embargo, muy pocos autores la consideran como una herramienta importante para predecir la durabilidad de la piedra.
Several other test methods use the softning role of water on clay-containing stones to get information on the presence and effect of clays. The slake durability test assesses the abrasion resistance of wet stone lumps, either in their natural condition (26, 29, 30) or after being pre-treated with ethyleneglycol (6). The ratio between compressive strength in wet (saturated) and dry conditions is also used to estimate the weakening effect of clay minerals, although the decrease in strength due to water might be due to other mechanisms besides clay swelling. This ratio was firstly described by L. Tetmajer (31) and adopted by other authors as a method to assessing the stone durability $(8,32)$.

Although requiring heavier instruments for its determination, the water-rock reactivity was considered as a good indicator of the presence of clay minerals inside rocks and together with the rock permeability and specific surface it was used for predicting the durability of stone materials (33).

These methods have been incorporated in assessment criteria or in suggested approaches for predicting the performance of clay-containing materials, but so far no serious effort has been made to build up a common understanding on the existing proposals or in the preparation of real alternatives to the existing ones. The following paragraphs discuss some of the available criteria aiming at bringing this subject into a more generalised discussion and, eventually, to trigger the development of better approaches to this important problem.

\section{SWELLING IN STONE CONSERVATION}

The quantitative determination of swelling strain is easy and straightforward. The required equipment is simple and inexpensive, the laboratory operation is pretty fast and the results very reliable. Apparently there are no reasons for the scarce availability of quantitative values in the bibliography, unless we argue that in this personal perspective the real importance of this parameter is overestimated.

Some of the already referenced papers originated in the field of stone conservation at least mention stone swelling as a relevant factor in the decay behaviour. However, very few address it as a major tool for predicting stone performance. 
En trabajos anteriores $(34,35)$ hemos presentado una propuesta para clasificar las rocas carbonatadas en función de su durabilidad potencial, utilizando la porosidad y la deformación por hinchamiento como parámetros para dicha clasificación. El ejemplo entonces presentado (Figura 2) y el uso subsiguiente de esta clasificación nos han demostrado que ésta continúa siendo una herramienta prometedora para predecir su comportamiento.' E. Winkler (32) sostiene que la relación entre los valores de resistencia en seco y en húmedo es suficiente para clasificar los materiales rocosos en términos de durabilidad y C. Félix (8) considera que combinando las relaciones de resistencia en seco y en húmedo y la tensión de hinchamiento la capacidad de predicción aumenta.

Como un paso más hacia la cuantificación hemos propuesto un Indice de Durabilidad de las Rocas (IRD) (9) con el propósito de abarcar un rango más amplio de materiales rocosos, además de las rocas carbonatadas consideradas en principio. La fórmula propuesta para el IRD es:
In previous papers $(34,35)$, we have presented a proposal for classifying the carbonate rocks in terms of their durability potential by using porosity and swelling strain as the entry parameters of that classification. The example at that time presented (Figure 2) and the subsequent use of such classification have shown that this continues to be a promising tool for predicting stone performance. $E$. Winkler (32) sustains that the ratio between wet and dry strength values is enough to classify stone materials in terms of durability and C. Felix (8) considers that combining the wet/dry ratio and the swelling strain increments the predicting capacity.

In a step towards quantification, we have proposed an IRD (Index of Rock Durability) (9) with the aim of reaching a wider range of stone materials besides the group of carbonate rocks considered firstly. The proposed formula for the IRD is:
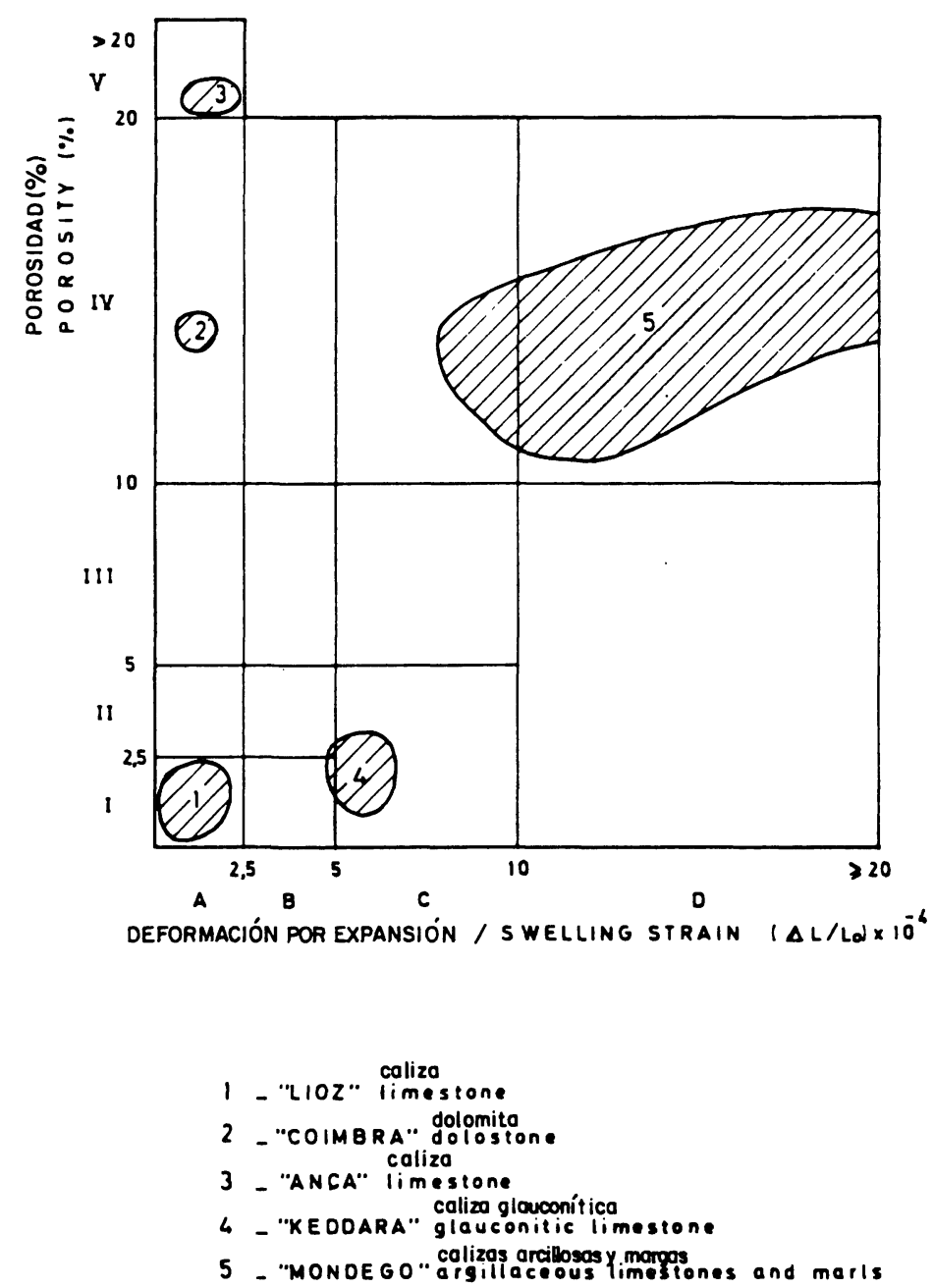

Figura 2.- Ábaco para la clasificación de rocas carbonatadas (tomado de Delgado Rodrigues, 1988 (35).

Figure 2.- Abacus for the clasification of carbonate rocs (reproduced from Delgado Rodrigues, 1988 (35). 
$\mathrm{IRD}=(\mathrm{Rc} / \mathrm{Rt}) /(\mathrm{n}+2 \mathrm{a})$

Donde:

$\mathrm{R}_{\mathrm{c}}$ : resistencia a compresión en $\mathrm{MPa}$

$\mathrm{R}_{\mathrm{r}}: 1 \mathrm{MPa}$ (para hacer el índice adimensional)

$\mathrm{n}$ : porosidad en porcentaje

a : mantisa de la deformación por hinchamiento, expresado como: $a \cdot 10^{-4}$

Al proponer este índice se considera que la porosidad y la deformación por hinchamiento integran la mayoría de los factores intrínsecos con incidencia negativa en el comportamiento de la roca, mientras que la resistencia a compresión integra los factores que ayudan al material a contrarrestar los factores deteriorantes.

La experiencia de los autores ha puesto de manifiesto la validez de este índice, pero trabajos posteriores han demostrado su potencial utilidad para un uso más amplio.

Ensayos de durabilidad en tuffs de la Capadocia (36) han demostrado que este índice es aplicable a rocas volcánicas y que el rango de predición concuerda con el obtenido por otros métodos de evaluación de la durabilidad de las rocas. Otros autores (37) que han usado este método consideran que las diferencias obtenidas entre los valores del IRD son lo bastante grandes como para discriminar las rocas en términos de durabilidad y afirman que "los tests de hinchamiento y los datos del IRD proporcionan una confirmación adicional del diferente comportamiento de los materiales rocosos".

En un trabajo reciente se evalúo la durabilidad de unas rocas completamente diferentes: algunas variedades de tuffs franceses (38); aunque en el trabajo no se utilizaron los IRD, a partir de los datos proporcionados se pueden elaborar estos índices y comparar con otros utilizados por los autores (Tabla1).

Del análisis de esta tabla se deduce que las dos variedades mejores (FONT y LUZE) a las cuales los autores han atribuido un comportamiento "bueno", presentan los IRD más altos, mientras que CHAM y LOUD muestran valores mucho más bajos, de acuerdo con la clasificación de su comportamiento como "pobre" y "medio". La muestra VILL no fue ensayada por los autores, pero su comportamiento en los tests de cristalización de sales indica que entraría en la clasificación de "pobre", lo cual, de nuevo, estaría de acuerdo con el bajo valor de su IRD. La muestra LOUD, cuyo comportamiento se ha clasificado como "medio", presenta un IRD de 0,15 el cual parece excesivamente bajo. De la lectura del trabajo no se
$I R D=\left(R_{c} / R_{p}\right) /(n+2 a)$

Where:

$R_{c}:$ compression strength, in $M P a$

$R_{t}$ : $1 M P a$ (for turning the index adimensional)

$n$ : porosity, in percent

a: mantissa of the swelling strain value when expressed as: $a \cdot 10^{-4}$

The leading idea underlying this index considers that porosity and swelling strain integrate most of the intrinsic factors with negative incidence in the rock behaviour, while compressive strength integrates the factors that help the material to counteract the decay factors.

The experience of the authors has shown the adequacy of this index, but subsequent independent works have also proved that it has potential for more extensive use.

The durability assessment of Capadocian tuffs (36) has shown that the index is applicable to volcanic rocks and has proved that the prediction range agrees with some other ways of assessing rock durability. Other authors (37) have used this method and considered that the differences obtained with IRD values are large enough for discriminating rocks in terms of durability, they state "A further confirmation of the different behavior is given by the swelling tests and by the IRD data".

In a recent paper (38), a completely different rock type -some varieties of the French "tuffeau" stoneis assessed for durability. Although IRD was not used, the data can be used for its computation. The computed values are the following (Table 1).

The analysis of this Table shows that the two best varieties (FONT and LUZE) to which the authors have attributed a "good" performance present the higher IRD values, while CHAM and LOUD show much lower values, in a fair agreement to their "poor" and "average" rating. The VILL sample was not assessed by the authors, but its performance in the salt crystalisation test points it as a "poor" rating, again in good agreement with its low IRD value. The value of IRD $=0.15$ for the LOUD sample seems excessively low for its "average" rating, but by reading the paper it was not possible to identify in it the reason for this "abnormal" IRD value. A 
Valores de IRD para los tuffs

(Values of IRD for the tuffeau stone)

\begin{tabular}{|c|c|c|c|}
\hline $\begin{array}{c}\text { Muestra* } \\
\text { (Sample)* }\end{array}$ & $\begin{array}{c}\text { ID Sales* } \\
(\text { IDSalt)* }\end{array}$ & $\begin{array}{c}\text { Durabilidad in situ* } \\
\text { (In situ performance)* }\end{array}$ & $\begin{array}{c}\text { IRD** } \\
(\text { IRD })^{* *}\end{array}$ \\
\hline CHAM & 4,7 & Pobre (Poor) & 0,14 \\
\hline FONT & 32,9 & Bueno (Good) & 0,45 \\
\hline LOUD & 22,0 & Medio (Average) & 0,15 \\
\hline LUZE & 31,3 & Bueno (Good) & 0,38 \\
\hline VILL & 2,8 & No observado (Not observed) & 0,14 \\
\hline
\end{tabular}

* Columnas tomadas directamente del trabajo original (38)

** Datos elaborados con fórmula IRD (9)

* (These columns were taken directly from the original paper (38))

** (Computed with the IRD formula (9))

desprende cuál puede ser la explicación de este valor anormal. Un mejor conocimiento de la representatividad de las muestras y de la variabilidad de los resultados podría ayudar a comprender su significación. A pesar de que los IRD fueron desarrollados para otro tipo de rocas completamente diferentes, su aplicación a este caso confirma la posibilidad de su uso para la evaluación de la durabilidad de las rocas.

Resultados previos (9) han puesto de manifiesto que las buenas variedades rocosas poseen valores muy altos de IRD, demostrando así que este índice presenta un rango muy amplio que permite clasificar adecuadamente todos los tipos rocosos.

Además de su utilidad para predecir la durabilidad de las rocas, el comportamiento expansivo ha sido analizado por su incidencia potencialmente negativa en rocas consolidadas. Algunos autores han utilizado las características expansibles de los materiales rocosos para demostrar los riesgos de la consolidación de la piedra $(39,40)$. Otros han propuesto el uso de pretratamientos específicos, tales como surfactantes, para reducir los eventuales riesgos (39). La aplicación de estos surfactantes a la arenisca de Khmer fue considerada eficaz en la reducción de su capacidad de hinchamiento (41).

La tradicional y muy precisa instrumentación de laboratorio utilizada para medir la deformación por hinchamiento se adaptó a las condiciones de campo y los autores (42) afirmaron que los resultados obtenidos fueron suficientemente buenos para demostrar el importante papel jugado por las arcillas expansibles en el comportamiento de las rocas egipcias estudiadas. better knowledge of the sampling representativeness and of the variability of results could eventually shed some light in its significance. In spite of being developed with basis in completely different stone types, the present values confirm the potential of the IRD formula for a first assessment of rock durability.

Previous results (9) have shown that good varieties of stone show very high IRD values thus demonstrating that the index has a large range of values where all rock types can find an appropriate place.

Besides its use as an element for predicting stone performance, the swelling behaviour has been analysed for its potential negative incidence when consolidation of stone is concerned. Some authors have made use of swelling characteristics of stone materials to show the risk of harmful effects in stone consolidation $(39,40)$. Others have even developed and proposed the use of specific pre-treatments, such as surfactants, in order to reduce those eventual risks (39). The application of these surfactants to the Khmer sandstone was considered successful in terms of reduction its swelling capacity (41).

The traditional and very accurate lab instrument used to measure the swelling strain was adapted to field conditions, the authors (42) claiming that their results were good enough to demonstrate the important role played by clay swelling in the performance of studied egyptian stones. 


\section{CONCLUSIONES FINALES}

Está reconocido universalmente que los componentes arcillosos inciden negativamente en el comportamiento de las rocas, especialmente cuando entran en contacto con fuentes de humedad. En el campo de la conservación de la piedra se menciona frecuentemente la importancia de las arcillas, pero muy pocos trabajos proporcionan información en términos cuantitativos de su capacidad expansiva, así como acerca del uso de esta propiedad para explicar el comportamiento presente o futuro de las rocas. Sin embargo, el test recomendado para medir la deformación por hinchamiento (43) es uno de los más simples y que requieren un equipamiento más barato, por tanto su valor es inestimable.

Para describir cualquier material rocoso, se pueden considerar muchos aspectos, dependiendo de la experiencia de los autores y del objetivo del estudio. Una descripción petrográfica correcta y el valor de la porosidad son elementos básicos que deberían considerarse esenciales y obligatorios. La cuantificación del potencial de hinchamiento debería ser tenida en cuenta como una información complementaria relevante en la caracterización de las propiedades intrínsecas de la roca y debería ser considerada obligatoria si las arcillas están presentes o si se sospecha de su presencia. La obtención de datos cuantitativos de la resistencia de la piedra es menos sencilla, pero es deseable, y no es raro encontrar valores de la resistencia a compresión en trabajos que tratan de la conservación de la piedra.

Una de las ideas conductoras de este trabajo es que estos parámetros sencillos y fáciles de obtener integran gran parte de la información relevante acerca de los factores intrínsecos que afectan al comportamiento de la piedra. Profundizando en esta idea, hemos propuesto el uso de un ábaco para clasificar las rocas carbonatadas y para predecir su durabilidad usando únicamente la porosidad y la deformación por hinchamiento como parámetros de entrada $(34,35)$. Posteriormente hemos tratado de generalizar la aplicación de esta idea y hemos propuesto una fórmula para cuantificar un Índice de Durabilidad de Rocas (IRD) usando la porosidad, la deformación por hinchamiento y la resistencia a compresión.

En los trabajos de investigación son escasos los valores de deformación por hinchamiento, por consiguiente es dificil encontrar datos adecuados para comprobar la validez de estos modelos interpretativos. Sin embargo, con los pocos datos disponibles, pudimos confirmar su validez y demostrar que se puede obtener gran cantidad de información útil con los sencillos parámetros utilizados en la fórmula del IRD.

\section{CONCLUDING REMARKS}

It is universally recognised that clays hamper the performance of rocks especially when they are in contact with moisture sources. In stone conservation, the importance of clays is frequently mentioned, but very few papers display quantitative information on the swelling potential and on its use to explain actual performances or to estimate future performance. However, the test setup used to measure swelling strain (43) is certainly one the simplest and cheapest equipments available, therefore its payback value is undoubtlessly a very high one.

For describing any stone material many issues can be considered, depending on the author's background and on the objectives of the study. A correct petrographic description and the porosity value are basic elements and should be considered essential and mandatory. The quantification of the swelling potential should be taken as a very relevant complementary component of the characterization of the stone intrinsic components and it should be considered mandatory whenever clays are present or suspected. Obtaining quantified data on the stone strength is less trivial but it is highly desirable and compression strength values are not so rare in papers dealing with stone conservation.

One leading idea of this paper sustains that these simple and easily available parameters integrate most of the relevant information on the intrinsic factors that affect the stone performance. Exploring this idea, we have proposed to use an abacus to classify carbonate rocks and to predict their durability solely by using porosity and swelling strain as entry parameters $(34,35)$. Subsequently, we tried to generalize the application of this idea and proposed a formula to compute an Index of Rock Durability where porosity, swelling strain and compressive strength are used.

Swelling strain values in research papers are scarce; consequently it is hard to find appropriate data to get a wide validation of these interpretation models. However, with the few ones where such values are presented we could confirm their validity and demonstrate that a lot of useful information can be obtained from the simple parameters used in the IRD formula. 
Cuando el potencial expasivo es importante, el comportamiento de la piedra puede verse drásticamente perjudicado y se requieren precauciones adicionales para solucionar o atenuar este hecho. Esta incidencia puede ser particularmente negativa cuando se trata de consolidar rocas y se han experimentado con éxito algunas medidas de tratamiento para contrarrestar estos efectos. Tal es el caso del uso de surfactantes para reducir la capacidad de hinchamiento de una roca antes de su consolidación $(39,41)$, pero los resultados prácticos son todavía escasos de modo que son necesarias más investigaciones en este tema.

\section{AGRADECIMIENTOS}

El autor agradece los comentarios y la ayuda de A.E. Charola en la revisión del manuscrito.
When the swelling potential is relevant, the stone behaviour can be drastically hindered and specific precautions are required to solve or to attenuate it. This incidence can be particularly threathening when stone consolidation is concerned and special treatment measures to counteract this effect have been experimented with some success. This is the case of using surfactants to reduce the swelling potential before consolidants are applied $(39,41)$, but practical results are still scarce and further research is still required in this particualr item.

\section{ACKNOWLEDGEMENTS}

The author acknowtedges the comments and help of A.E. Charola in the revision of the manuscript.

\section{BIBLIOGRAFÍA}

(1) Weinert, H. 1968 - "Engineering petrology for roads in South Africa". Engng. Geology, Vol. 2, no.6, nov. 1968.

(2) Thénoz, B., Pérami, R. et Capdecomme, L. 1966 - "Sur l'arénisation et l'altération en boules des granites". Actes de la Soc. Linnéenne de Bordeaux, Vol. Spécial, Congrès AFAS 1967, Bordeaùx, 1968.

(3) Struillou, R. 1968 - "Prévision de l'altérabilité des matériaux employés en génie civil". Colloque de Géotechnique, Toulouse, mars, 1969.

(4) Drew, E.D. and Woods, H.D. 1970 - "Deterioration of riprap at Waddell Bluffs, Iv-SCr-1, and an evaluation of physical tests as a method of determining the durability of stone for riprap". Bank and Shore Protection in California Highway Practice, Dep. Pub. Works Bus. Transp. Agency, Sacramento Dep, 1970.

(5) Tourenq, C. et Denis, A. 1970 - "La résistence à la traction des roches". LCPC Rapport de Recherche, No.4, Paris, 1970.

(6) Delgado Rodrigues, J. 1976 - "Estimation of the content of clay minerals and its significance in stone decay". Proc. $2^{\text {nd }}$. Int. Symp. On Deterioration of Building Stones, Athens, 1976.

(7) Félix, C. and Furlan, V. 1982 - "Mesures automatiques sur des faciès gréseux de la dilatation linéaire isotherme para absorption d'eau dans différentes conditions". Proc. $4^{\text {th }}$ Int. Cong. on Deterioration and Preservation of Stone Objects, Louisville (Ky.)(1982), pp. 127-134.

(8)Félix, C. 1988 - "Comportement des grès utilisés en construction sur le Plateau suisse". Proc. Int. Symp. On the Engineering Geology of Ancient Works, Monuments and Historical Sites, Athens, Edited by P. Marinos and G. Koukis, Balkema, pp. 833-841.

(9) Delgado Rodrigues, J. and Jeremias, F.T. 1990 - "Assessment of rock durability through index properties". Proc. $6^{\text {th }}$. Int. Cong. of IAEG, Amsterdam, Edited by D.G. Price, Balkema (1990), pp. 3055-3060.

(10) Rodríguez-Navarro, C., Hansen, E., Sebastian, E.and Ginell, W.S. 1997 - "The role of clays in the decay of ancient Egyptian limestone sculptures", JAIC 36(1997), pp. 151-163.

(11)Wüst, R.A.J. and McLane,J. 2000 - "Rock deterioration in the royal tomb of Seti I, Valley of the Kings, Luxor, Egypt". Engineering Geology 58(2000), pp. 163-190.

(12) De Vecchi, G., Rossetti, M. and Vannucci, S. 1991 - "La serpentina della cattedrale di S. Maria del Fiore a Firenze ed il suo degrado".

Le Pietre nell' architettura: Struttura e Superficie, Atti del Convegno di Studi, Bressanone, 1991, Libreria Progetto Ed., Padova, pp. $247-256$.

(13)Fratini, F., Ceccherini, S.,Pecchioni, E., Manganelli del Fá, C., Scala, A. and Galletti, G. 1991 - "Alterazione del marmo e della serpentinite costituenti il rivestimento della facciata della collegiata di s. Andrea in Empoli (Firenze)". Le Pietre nell' Architettura: Struttura e Superficie, Atti del Convegno di Studi, Bressanone, 1991, Libreria Progetto Ed., Padova, pp. 323-344.

(14)Ventikou, M.; Halls, C., Lindsay, W., Batchelder, M. and Hubbard, C. 2000 - "An evaluation of geology and weathering in the preservation of marl objects". $9^{\text {th }}$ Int. Cong. on Deterioration and Conservation of Stone, Venice. Edited by V. Fassina, Elsevier, pp. 283-291.

(15) Helmi, F.M. 2000 - "Geoegyptology of A-Muzawaka tombs, Dakhla Oases, Egypt". 9 th Int. Cong. on Deterioration and Conservation of Stone, Venice. Edited by V. Fassina, Elsevier, pp. 99-107.

(16) Rodriguez-Navarro, C., Sebastian, E., Doehne, E. and Ginell, W.S. 1998 - "The role of sepiolite-palygorskite in the decay of ancient Egyptian limestone sculptures", Clays and Clay Minerals, Vol. 46, No.4(1998), pp. 414-422.

(17) Ruiz, M.D. 1963 - "Mecanismo de desagregação de rochas basálticas semi alteradas". Anais do II Cong. Panamericano de Mecânica dos Solos e Engenharia de Fundações, Vol. 1, pp. 533-543.

(18) Scott, L. 1955 - "Secondary minerals in rock as a cause of pavement and base faillure". Highway Res. Board, Proc., pp. $412-417$.

(19) ASTM C 837-81 -"Standard test method for methylene blue index of clay". Annual Book of ASTM Standards, Vol. 15.02, 1989.

(20) Ngoc Lan, T. 1980 - "L'essai au bleu de méthylène. Un progrés dans la mesure et le controle de la properté des granulats". Bull. Liaison

Lab. Ponts et Chaussées, No. 107, mai-juin 1980.

(21) Stapel, E.E. and Verhoef, P.N.W. 1989 - "The use of the methylene blue test in assessing the qaulity of basaltic tuff rock aggregate". Engineering Geology, 26,pp. 233-246.

(22)Kergoet, M. and Cimpelli, C. 1980 - "Appréciation d'un comportement de sable fin poluéparl'essai au bleu demethylène". Bull. Liaison Lab. Ponts et Chaussées,, No.108, juillet-août, 1980. 
(23) Nascimento, U., Oliveira, R. and Graça, R.C. 1968 - "Rock swelling test". Int. Symp. on Rock Mechanics, Madrid, pp. 363-365.

(24)RILEM 1980 - "Essais recommandés pour mesurer l'altération des pierres et évaluer l'éfficacité des méthodes de traitement". Matériaux et Constructions, 13(1980), pp. 175-252.

(25) Duncan, N., Dunne, M.H. and Petty, S. 1968 - "Swelling characteristics of rocks". Water Power, May, pp. 185-192.

(26) ISRM, 1979 - "Suggested methods for determining water content, porosity, absorption and related properties and swelling and slakedurability index properties". Int. Jour. Rock Mech. and Min. Sciences \& Geomech. Abstr., Vol. 16, pp. 141-156.

(27) Huder, J. and Amberg, G. 1970 - "Quellung im Mergel, Opalinuston und Anhydrit", Schweiz. Bauzeitung, Heft 43.

(28)Kovári, K., Amstad, Ch. and Anagnostou, G. 1988 - "Design/construction methods-Tunnelling in swelling rocks". Key Questions in Rock Mechanics, Cundall et al. (eds.), Balkema, Rotterdam.

(29) Gamble, J.C. 1971 - "Durability-plasticity of shales and other argillaceous rocks". Thesis, Univ. Illinois at Urbana, Champain, Illinois, 1971.

(30) Franklin, J.A. and Chandra, R. 1972 - "The slake-durability test". Int. Jour. Rock Mechanics and Mining Sciences, Vol. 9, pp. 325-341.

(31) Tetmajer, L., 1884 - "Methoden und Resultate der Pruefung Natuerlicher und Kuenstlichter Bausteine. In Mitteilungen der Anstalt fuer Pruefung von Baumaterialen am Eidg". Polytechnikum in 32Auerich, No. 1:Zuerich, Switzerland, Commissionverlag von Meyer and Zeller, 1884, pp. 59. (Quoted in Carr, D.D., Strickland, J., McDonald, W.H. and Bortz, S. 1996 - "Review of durability testing of building stone with annotated bibliography". Journal of Testing and Evaluation, JTEVA, Vol. 24, No. 5, September 1996, pp. 324-328).

(32) Winkler, E.M. 1986 - "A durability index for stone". Association of Engineering Geologists Bulletin, Vol. 23, 1986, pp. $344-347$.

(33) Farran, J. et Thénoz, B. 1965 - " L'altérabilité des roches, ses facteurs, sa prévision". Annales de l'ITBTP, XVIIrème année, nevembre.

(34) Delgado Rodrigues, J. 1985 - "Proposta para uma classificação geotécnica de rochas carbonatadas". Geotecnia, No.44, july 1985, pp. 119-123.

(35) Delgado Rodrigues, J. 1988 - "Proposed geotechnical classification of carbonate rocks based on Portuguese and Algerian examples". Engineering Geology, 25,(1),pp. 33-43.

(36) Topal, T. and Doyuran, V. 1997 - "Engineering geological properties and durability assessment of the Cappadocian tuff". Engineering geology, Vol.47,pp. 175-187.

(37)Langella, A., Calcaterra, D., Cappelletti,P.,Colella, A.,de'Gennaro, M. and de Gennaro, R. 2000 - "Preliminary contribution on durability of some macroporous monumental stones used in historical towns of Campania region, southern Italy". $9^{\text {th }}$ Int. Cong. on Deterioration and Conservation of Stone, Venice, Edited by Vasco Fassina, Elsevier, Amsterdam, Vol.1, pp. 59-67.

(38)Dessandier,D., Bromblet, P. and Mertz, J.-D. 2000-"Durability of tuffeau stone in buildings: influence of mineralogical composition and microstructural properties". $9^{\text {th }}$ Int. Cong. on Deterioration and Conservation of Stone, Venice, Edited by Vasco Fassina, Elsevier, Amsterdam, Vol.1,pp.69-78.

(39) Wendler, E., Klemm, D.D. and Snethlage, R. 1990 - "Consolidation and hydrophobic treatment of natural stone". Fifth Int. Conf. on Durability of Building Materials and Components, Brighton, nov. 1990.

(40) Félix, C. 1994 - "Déformations de grès consécutives à leur consolidation avec un silicate d'éthyl".tサnt. IAEG Cong. Lisbon, Balkema, Publs., Roterdam, pp. 3543-3550.

(41) Wendler, E. and Prasartset, C. 2000 - "Old Khmer styled sandstone monuments in Thailand. Aspects of weathering and development of a conservation concept". $9^{\text {th }}$ Int. Cong. on Deterioration and Conservation of Stone, Venice, Edited by Vasco Fassina, Elsevier, Amsterdam, Vol.2,pp. 765-774.

(42)Zehnder, K., Arnold, A. and Küng, A. 2000 - "Weathering of painted marly limestones in the temple ruin of Merenptah, Qurna/Luxor (Egypt)". $9^{\text {th }}$ Int. Cong. on Deterioration and Conservation of Stone, Venice, Edited by Vasco Fassina, Elsevier, Amsterdam, Vol. 2, pp. 749 757.

(43) RILEM 1980 - "Tentative Recommendations. Linear strain due to water absorption". Matériaux et Construtions, vol. 13 , No. 75.

Nota de redacción

El Comité de Redacción de la Revista agradece a $\mathrm{D}^{\mathrm{a}}$ Benita Silva la traducción al español y la revisión técnica del manuscrito. 